DOI: https://doi.org/10.47405/mjssh.v5i8.455

\begin{tabular}{|c|c|}
\hline 4 & Malaysian Journal of Social Sciences and Humanities (MJSSH) \\
\hline $\begin{array}{l}\text { Malaysian Journal of } \\
\text { Social sciences and }\end{array}$ & Volume 5, Issue 8, August 2020 \\
\hline (MJ-SSH) & e-ISSN : 2504-8562 \\
\hline & $\begin{array}{l}\text { Journal home page: } \\
\text { www.msocialsciences.com }\end{array}$ \\
\hline
\end{tabular}

\title{
Takrifan Autoriti Sebagai Wacana Realiti Sosial dalam Kempen Bulan Penghayatan Kebangsaan
}

\author{
Sitinurbayu Binti Mohd Yusoff'1, Syahruddin Ag Ahmad1, Aisah Meri'1, Cyril Modili1 \\ ${ }^{1}$ Fakulti Sains Sosial dan Kemanusiaan, Universiti Malaysia Sabah (UMS) \\ Correspondence: Sitinurbayu Binti Mohd Yusoff (bayu.yusoff@ums.edu.my)
}

\begin{abstract}
Abstrak
Setiap tahun, perayaan Hari Kebangsaan disambut meriah dengan pelbagai kempen dan program anjuran kerajaan bagi menyuntik semangat patriotisme dan nasionalisme di kalangan masyarakat. Sambutan perayaan Hari Kebangsaan ini dianjurkan dengan harapan ia dapat membina jiwa kenegaraan yang tinggi dalam kalangan masyarakat yang majmuk. Pengisian dalam kempen Hari Kebangsaan adalah sepenuhnya menjadi tanggungjawab kerajaan untuk mengatur pelan strategi yang paling sesuai dengan keadaan masyarakat Malaysia yang berbilang bangsa dan agama. Di sini, pengaruh realiti sosial takrifan autoriti dijangka memainkan peranan dalam mengawal situasi untuk mengekalkan sesuatu penguasaan yang telah diperolehi. Oleh itu, wacana tentang kemerdekaan yang diketengahkan oleh pihak kerajaan melalui kempen bulan Kebangsaan saban tahun harus dirancang dengan teliti agar kewibawaan, konsep dan motif yang direncanakan dalam sesebuah kempen dapat dihayati dengan sepenuh hati oleh golongan sasar. Dalam masa yang sama kebijaksanaan kerajaan dalam merangka kandungan kempen perlu agar integriti kerajaan dalam memimpin negara diperolehi dan dipandang tinggi di mata dunia. Kaedah perbincangan kumpulan fokus dan temubual mendalam telah dijalankan untuk mengenalpasti adakah wujudnya unsur 'authority-defined' dalam pemilihan isi kandungan kempen bulan Kebangsaan. Dapatan yang digarap daripada perbincangan kumpulan fokus dan temu bual mendalam dikaitkan dengan konsep realiti sosial takrifan autoriti sebagai pemangkin kepada pembentukan terhadap penguasaan dalam kalangan rakyat negara ini. Kajian ini diharap dapat memberikan pemahaman yang lebih jelas mengapa konsep takrifan autoriti (authority-defined) itu lebih penting untuk dipraktiskan dalam pengurusan sesebuah pemerintahan berbanding amalan takrifan harian (everyday-defined).
\end{abstract}

Kata kunci: realiti sosial, takrifan sosial, hari kebangsaan, takrifan harian

\section{Authority-Defined As Social Reality Discourse in National Day Campaign}

\begin{abstract}
Each year, National Day celebrations are celebrated with various government-sponsored campaigns and programs to inject the spirit of patriotism and nationalism into the community. The celebration of the National Day is organized in the hope that it will build a high spirit among multiracial citizenship. It is entirely the government's responsibility to formulate a strategic plan for the National Day Campaign that is best suited to the condition of the multiracial among Malaysian community. The social reality influence of authority-defined is expected to play a role in controlling the situation through campaign in order to maintain an acquired power. Therefore, the discourse on independence promoted by the government through the National Day Campaign each year should be carefully
\end{abstract}


planned so that the integrity, concepts and motives planned in a campaign can be fully appreciated by the target group. At the same time, the government's wisdom in formulating the content of the campaign is essential for the government's integrity in leading the country. Focus group discussion methods and in-depth interviews were conducted to identify the existence of 'authority-defined' elements in the selection of the contents of the National Day Campaign. The findings from the focus group discussions and in-depth interviews are linked to the concept of social reality of authoritydefined as a catalyst for the formation of dominance among the people of this country. It is hoped that this study will provide a clearer understanding of why the concept of authority-defined is more important to be practiced in the management of a government than the practice of everyday-defined.

Keywords: social reality, authority-defined, national day, everday-defined

\section{Pengenalan}

Kemerdekaan sesebuah negara adalah simbol kebebasan yang menggambarkan semangat juang dan kemahuan untuk tidak dijajah oleh pihak lain. Justeru, kemerdekaan sebuah negara seperti Malaysia juga memperlihatkan jati diri rakyatnya yang mahu kekal hidup dalam kebebasan dalam erti kata yang luas mencakupi aspek kehidupan sebagai warganegara yang peka kepada semua perkara termasuklah usaha untuk mengekalkan kebebasan itu dalam era pasca kemerdekaan.

Demi menanamkan benih semangat kebangsaan dan patriotik ini, maka, pihak kerajaan telah mengekalkan sambutan Hari Kebangsaan pada $31 \mathrm{hb}$ Ogos setiap tahun dan 16hb September sebagai hari pembentukan Malaysia. Ritual sambutan Hari Kebangsaan ini adalah petunjuk bahawa masyarakat di negara ini masih mengenang jasa bakti para pejuang kemerdekaan dalam usaha mereka memperoleh kemerdekaan daripada pihak penjajah British. Demikianlah juga dengan pembentukan Malaysia yang secara harfiah menunjukkan kesatuan wilayah di negara ini dilakukan dengan tujuan untuk mengukuhkan kedaulatan negara ini menerusi penyatuan wilayah di Borneo dan Persekutuan Tanah Melayu.

Aspek kesedaran terhadap peri pentingnya memelihara kebebasan dalam pemerintahan, kedaulatan wilayah dan perpaduan bangsa dalam negara Malaysia pasca kemerdekaan dan pembentukan Malaysia jelas dipamerkan menerusi kempen penghayatan Hari Kebangsaan yang dirayakan setiap tahun. Setiap entiti dalam negara ini diyakini boleh menzahirkan rasa memiliki dan menyayangi kemerdekaan dengan mempamerkan sokongan dalam semua perkara yang melibatkan usaha merangsang semangat cintakan negara.

Secara tersurat, sambutan Hari Kebangsaan yang disambut setiap tahun adalah ritual rasmi tentang tarikh keramat kemerdekaan Persekutuan Tanah Melayu dan semestinya membawa makna tersirat tentang nilai perjuangan tokoh-tokoh kemerdekaan dalam merealisasikan kebebasan tanahair daripada cengkaman penjajah. Namun, sambutan Hari Kebangsaan hanya tinggal sebagai acara atau tempat orang awam berkumpul semata-mata sekiranya program tersebut tidak dapat dijiwai sebagai acara yang sepatutnya menaikkan semangat cintakan negara dan dalam masa yang sama menanamkan semangat perjuangan untuk mengekalkan kebebasan negara dan rakyat daripada pengaruh anasir-anasir bahaya yang boleh mengancam kedaulatan negara.

Anasir-anasir subversif seperti ideologi politik yang berlawanan dengan kepercayaan politik di negara ini serta budaya asing yang boleh menghakis jati diri masyarakat tempatan seharusnya dilihat sebagai ancaman dari luar. Manakala, pemikiran yang sempit terhadap nilai dan norma masyarakat tempatan, sikap mementingkan diri dan bangsa sendiri yakni perkauman serta budaya popular serba sedikit berpotensi menjadi ancaman dari dalam masyarakat di negara ini.

Terdapat kemungkinan, kedua-dua ancaman dari luar dan dalam masyarakat Malaysia ini menjadi sebab kepada kurangnya sokongan terhadap acara-acara sambutan Hari Kebangsaan di semua peringkat khasnya dalam kalangan generasi muda (Noor Mohamad, 2012; Iskandar, 2017). 
Sungguhpun begitu, wacana tentang nilai kemerdekaan yang diterapkan ke dalam kempen bulan Kebangsaan oleh agensi kerajaan yang berkaitan saban tahun memungkinkan peningkatan tahap kesedaran belia terhadap pentingnya semangat patriotisme dalam diri.

Apa yang penting adalah, usaha kerajaan melalui media massa dan media atas talian khususnya media sosial kini dilihat sebagai optimistik dan secara teknikalnya telah membantu menjayakan kempenkempen kesedaran Hari Kebangsaan yang dirancang dan dilaksanakan secara berterusan. Kempen yang berulang dan berterusan ini sekurang-kurangnya dapat membuka mata semua pihak tentang kemahuan kerajaan untuk mengekalkan semangat kebangsaan dan patriotisme sampai bila-bila. Kempen-kempen kesedaran untuk memupuk semangat mencintai negara ini pula sepatutnya merentas semua elemen budaya serta adat resam satu-satu kaum, bahasa, jantina, umur dan taraf pendidikan rakyat negara ini.

\section{Kempen Penghayatan Hari Kebangsaan}

Kempen penghayatan Hari Kebangsaan merupakan salah satu mekanisme penting yang sering ditonjolkan dalam sambutan ulangtahun kemerdekaan negara. Kerajaan tanpa gagal, akan pasti menganjurkan kempen penghayatan Hari Kebangsaan bagi meraikan hari 'kemenangan' ini disamping berusaha menyuntik semangat patriotisme dalam diri masyarakat. Antara kempen penghayatan Hari Kebangsaan yang dianjurkan kerajaan adalah Program Kembara Merdeka, Kempen Kibar Jalur Gemilang, Pertandingan Mencipta Logo Hari Kebangsaan, Pertandingan Keceriaan Bulan Kebangsaan dan sebagainya. Tidak ketinggalan juga kandungan kempen oleh media massa seperti iklan, lagu patriotik, Pertandingan Puisi Merdeka dan banyak lagi.

Bagi menyokong acara dalam sambutan bulan Kebangsaan, program MERDEKA@KOMUNITI telah dilancarkan pada tahun 2016. Program ini telah dikenalpasti menjadi salah satu segmen dalam sambutan bulan Kebangsaan bermula tahun 2016 sehingga tahun 2018. Kesan yang diperolehi menerusi program tersebut adalah jelas menunjukkan keghairahan orang ramai mengadakan pelbagai aktiviti sempena sambutan bulan Kebangsaan. Masyarakat memberi tindakbalas dan respon yang positif terhadap program MERDEKA@KOMUNITI itu sehinggakan fenomena sambutan yang meluas di seluruh negara bukan sahaja berlaku di ibu negeri, daerah, pekan kecil tetapi juga sehingga ke kawasan kampung dan pedalaman (www.penerangan.gov.my). Antara aktiviti-aktiviti yang dilaksanakan ialah pemasangan bendera, Bicara Tokoh, penyampaian Jalur Gemilang, Ambang Merdeka, Tayangan Layar Bestari dan aktiviti rekreasi. Melalui program sebegini semangat patriotik dalam kalangan masyarakat boleh diterapkan di samping memeriahkan lagi sambutan bulan Kebangsaan pada setiap tahun.

Usaha membina masyarakat belia yang mempunyai idealisme perjuangan dalam gelombang arus perubahan kebendaan yang berlaku sekarang merupakan satu cabaran yang amat besar. Ketandusan dan kelunturan semangat patriotik belia pada masa ini telah banyak diperkatakan atas keprihatinan yang menyentuh isu kesinambungan perjuangan generasi masa depan (Abd. Rahim, 2004). Kempen Kibar Jalur Gemilang dikenalpasti masih kurang mendapat sambutan dalam kalangan masyarakat. Tidak ramai masyarakat prihatin yang mengambil inisiatif untuk mengibar Jalur Gemilang menjelang sambutan Hari Kebangsaan. Maka, pada tahun 2019, kerajaan telah berusaha untuk meningkatkan kesedaran masyarakat terhadap semangat patriotisme menerusi Kempen Kibar Jalur Gemilang. Usaha ini dianggap penting sementelah Jalur Gemilang merupakan lambang kedaulatan negara. Justeru, kerajaan bertekad untuk mempergiatkan kempen tersebut khususnya di peringkat akar umbi agar Jalur Gemilang dapat berkibar dengan megah di sekolah-sekolah, di pejabat kerajaan mahupun agensi swasta, di kedai-kedai, di kampung-kampung juga di bandar-bandar besar (Gobind Singh Deo, 2020).

Di peringkat awal sambutan Hari Kebangsaan, acara yang dirancang untuk dijayakan hanyalah berasaskan kepada tema sahaja. Tema Hari Kebangsaan telah diwujudkan pada tahun 1970 berikutan peristiwa berdarah yang berlaku pada 13 Mei 1969. Berikutan peristiwa tersebut, negara telah diisytiharkan darurat. Maka pada tahun 1970, masyarakat telah menyambut Hari Kebangsaan dengan dibayangi oleh rasa kebimbangan akan berulangnya peristiwa tersebut. Kelonggaran ikatan perpaduan dikalangan masyarakat majmuk dikenalpasti telah menjadi salah satu punca tercetusnya peristiwa 13 Mei ini (Abd. Rahim, 2004). Berikutan daripada peristiwa tersebut, pada tahun 1970, sambutan Hari 
Kebangsaan buat pertama kalinya diteraskan kepada tema iaitu "Muhibbah dan Perpaduan". Ini merupakan antara usaha yang dilakukan oleh kerajaan untuk membaikpulih ikatan perpaduan yang telah longgar dan berusaha membina masyarakat Malaysia yang lebih harmoni serta bertoleransi.

Kempen penghayatan Hari Kebangsaan dijangka dapat berfungsi sebagai mekanisme komunikasi dalam menyampaikan mesej yang jelas dan jitu tentang masyarakat dan negara pada waktu sambutan Hari Kebangsaan. Hal yang demikian akan dapat membantu kerajaan untuk membibitkan aspirasi bagi memajukan negara menerusi semangat patriotisme dan nasionalisme dalam kalangan masyarakat.

\section{Objektif Kajian}

Kajian ini bertujuan untuk memberikan gambaran sebenar realiti sosial yang berlaku dalam tampuk pemerintahan di negara ini dengan memahami erti sebenar perbezaan antara konsep realiti sosial takrifan autoriti dan realiti sosial takrifan harian menerusi kempen penghayatan Bulan Kebangsaan khususnya tahun 2016-2018. Sungguhpun negara Malaysia ini dikatakan sebuah negara demokrasi semenjak mencapai kemerdekaan pada tahun 1957 (Zarina Othman et al., 2016) namun ada batas-batas yang perlu dipatuhi dalam mengekalkan integriti sesebuah pentadbiran. Hobsbawm \& Ranger (1983) menyatakan bahawa acara seperti Hari Kemerdekaan dan pertabalan Raja dalam sesebuah negara bukanlah tradisi semulajadi yang diamalkan tetapi ianya dicipta oleh pihak yang dominan (autoriti) untuk memberi mesej kepada rakyat jelata bahawa mereka memegang teraju kuasa sebenar dalam sesuatu pemerintahan. Terdapat usaha di pihak kerajaan untuk menampilkan imej dan reputasi agensi serta kepimpinan kerajaan yang cemerlang dalam acara dan poster sempena bulan penghayatan Hari Kebangsaan.

\section{Sorotan Literatur}

Autoriti merupakan salah satu konsep utama dalam falsafah politik. Biasanya didefinasikan sebagai cara pengaruh yang berbeza dari paksaan dan pemujukan dengan hujah. Christopher (1994) menyatakan bahawa terdapat tiga jenis autoriti dalam pemerintahan. Autoriti ahli, autoriti yang didasarkan kepada janji untuk dipatuhi dan autoriti yang memudahkan kerjasama yang saling menguntungkan dalam satu kumpulan. Ujar beliau lagi hujah untuk demokrasi dalam bidang politik, iaitu, hujah untuk pemerintahan demokratik, biasanya tidak bergantung pada nilai penyertaan. Sebaliknya, mereka mendakwa bahawa hanya pemerintah demokratik yang dapat memegang kuasa politik yang sah. Tegas Christopher (1994) lagi, kewibawaan yang difahami sangat diperlukan untuk pengurusan dalam kumpulan besar. Ianya adalah mustahil untuk memaksa atau meyakinkan semua orang. Bagi sesebuah autoriti, kuasa yang paling penting adalah keupayaan untuk membuat kehidupan orang lain seperti yang diinginkan oleh mereka dan terutamanya kuasa untuk membuat mereka melakukan perkara-perkara tertentu. Dengan kata lain, autoriti adalah kemampuan satu-satu pihak untuk membuat keputusan dan bertindak dan dalam masa yang sama diikuti keputusan serta tindakan tersebut oleh pihak yang dikuasai.

Hujah teori semantik menggambarkan fenomena realiti sosial takrifan autoriti di Malaysia serta memperlihatkan usaha kerajaan dalam menerapkan unsur penguasaan melalui kempen penghayatan bulan Kebangsaan. Berpandukan teori ini dijangka membantu penyelidik mengupas bentuk hubungan antara pemerintah dengan masyarakat golongan sasar berasaskan konsep-konsep yang dikaji. Dengan kata lain, teori semantik berupaya membantu pengkaji untuk melihat makna di sebalik gambaran atau imej yang ada dalam fikiran seseorang. Maksudnya, apabila sesuatu perkataan itu disebut, didengar atau dibaca oleh seseorang maka fikirannya akan menggambarkan sesuatu yang berkaitan dengan makna perkataan, frasa atau satu-satu konsep lain. Contohnya, kempen penghayatan Hari Kebangsaan. Setiap mesej berunsur patriotik yang diterapkan dalam mekanisme kempen Hari Kebangsaan cuba dihurai berdasarkan gambaran yang ada dalam fikiran informan semasa sesi perbincangan kumpulan fokus dijalankan.

Secara umum, makna di sebalik sesuatu simbol dapat dianalisis melalui dua cara iaitu melalui analisis secara semantik dan analisis secara pragmatik. Pendekatan analisis secara semantik merupakan kajian 
mengenai hubungan antara simbol dengan rujukan atau boleh juga dikatakan hubungan antara perkataan dengan benda. Pendekatan analisis pragmatik pula membantu penyelidik untuk memahami hubungan antara simbol atau perkataan dengan perlakuan yang ditunjukkan oleh seseorang sebagai reaksi kepada simbol atau perkataan yang ditunjukkan kepadanya. Reaksi yang pelbagai bergantung kepada tanggapan seseorang. Di sini, elemen pragmatik jelas dalam mengaitkan antara usaha kerajaan untuk mendorong wujudnya semangat patriotisme menerusi kempen Hari Kebangsaan itu.

Pengkajian subjek dalam semantik umum seharusnya mengambilkira aspek wacana yang secara prinsip diyakini dapat membantu proses perbincangan mengikut urutan yang tetap dan betul sama ada ia melibatkan komunikasi idea, lisan dan bukan lisan, yang bersifat rasmi dan teratur (Ismail, 1994). Sekiranya kita menggunakan definisi ini sebagai rujukan, maka semua tulisan itu dianjurkan, yang dalam urutan yang betul atau logik, adalah wacana. Kerana itu, wacana mesti mempunyai dua elemen penting, iaitu perpaduan dan koheren (Sobur, 2001). Lull (1998) pula menyatakan bahawa wacana bermaksud cara objek atau idea dibincangkan secara terbuka kepada orang awam yang boleh menimbulkan pemahaman yang luas.

Dari dimensi kajian bahasa, wacana adalah unit bahasa yang sering digunakan oleh pengkaji linguistik masa kini. Banyak pengertian merangkumi perkataan wacana ini. Dalam bidang sosiologi, wacana merujuk kepada hubungan konteks sosial dari penggunaan bahasa. Manakala, dari sudut linguistik, wacana ditakrifkan sebagai unit bahasa yang lebih besar daripada ayat. Hal ini disahihkan oleh Asmah (1986) dengan menegaskan bahawa wacana ialah unit bahasa yang melebihi batas ayat, yang membina hubungan-hubungan dan perkembangan fikiran yang berurutan seperti ayat, sejumlah ayat, ceraian, perenggan, bab, buku, novel, cerpen dan sebagainya. Pendapat Asmah ini disokong oleh Harimurthi (1984). Beliau menjelaskan bahawa wacana ini direalisasikan dalam bentuk karangan yang utuh seperti novel, buku, ensiklopedia dan sebagainya.

Asmah juga menyatakan bahawa, wacana tidak mempunyai satu-satu jenis ayat yang terdiri dengan utuhnya tanpa dipengaruhi oleh proses-proses pembentukan ayat. Wacana ialah keseluruhan pelahiran bahasa oleh penutur atau penulis, iaitu sistem bahasa dan unsur-unsur luar daripada sistem bahasa yang menyumbang ke arah menjadikan pertuturan atau tulisan berkenaan sebagai sesuatu yang bermakna dalam berkomunikasi.

Aspek unsur-unsur luar ini dihujahkan oleh Syahruddin (2015) sebagai suatu perlakuan lisan dan tulisan yang ideal kini boleh dikesan wujud dalam persekitaran tempatan. Kajian beliau mendedahkan fungsi satu-satu wacana yang hakikatnya berkaitrapat dengan aspek peranan wacana dan kesannya kepada masyarakat. Hal tersebut menjelaskan bahawa wacana yang memuatkan konsep perlakuan lisan yang ideal berfungsi sebagai satu kaedah mempersembahkan aliran pemikiran yang boleh membantu seseorang ahli masyarakat menerapkan ideologi dan aspirasinya kepada ahli masyarakat yang lain mengikut konteks isu atau situasi semasa dalam masyarakat tersebut.

Dari segi bahasa, Harimurthi (2009) menyatakan wacana adalah kesatuan bahasa terlengkap dan merupakan kesatuan gramatikal tertinggi dalam hierarki gramatikal. Hal tersebut menjelaskan bahawa wacana adalah satuan bahasa lengkap dan tertinggi atau terbesar di atas kalimat atau klausa dengan koherensi dan kohesi tinggi yang berkesinambungan yang mempunyai awal dan akhir nyata disampaikan secara lisan atau tertulis (Tarigan, 2009).

Seterusnya, Idris (2000) dalam kajiannya menyatakan bahawa bahasa dalam konteks tulisan ini diertikan sebagai wacana atau language use atau performance (ketrampilan), iaitu bahasa yang benarbenar digunakan, dan bukannya data bahasa yang dibuat-buat, seperti yang sering diamalkan dalam linguistik aliran transformasi generatif. Hal tersebut menjelaskan bahawa wacana adalah sebarang jenis penggunaan bahasa sebenar yang bermakna dan lengkap, sama ada bertulis atau lisan, monolog atau dialog.

Analisis wacana dilakukan untuk mendapat pemahaman yang lebih jelas terhadap teks dan bagaimana ia memberi makna yang berguna kepada penggunanya. Analisis wacana dilakukan untuk mencari maksud yang tertanam di dalam warna, nombor, imej dan sebagainya. Analisis wacana membantu dalam 
mencari maksud yang dibina oleh seseorang yang kita tidak nampak (Sitinurbayu \& Badrul, 2014). Dari sudut teoritis, analisis kritis wacana media mencakupi segala aktiviti menyerlahkan semiotik secara lisan, bukan lisan hinggalah penonjolan mesej wacana menerusi media visual seperti filem, video, fotografi dan grafik yang terwacana melalui struktur dan strategi komunikasi yang sering beroperasi di bawah paras sedar (sub conscious) khalayak media (Badrul \& Faridah, 2012).

Justeru, konsep wacana dalam media boleh disimpulkan sebagai wadah atau platform yang bersifat praktikal dalam membantu pihak berkepentingan untuk menyampaikan mesej kepada kumpulan sasar. Dalam masa yang sama, wacana juga boleh dibina sebagai doktrin, falsafah dan norma yang diterapkan ke dalam minda sekumpulan manusia yang dijangka dapat memberikan impak tertentu terhadap satusatu perkara atau pihak yang mempunyai kepentingan. Dalam konteks pemerintah, keutamaan wacana adalah menjurus kepada usaha pihak kerajaan untuk memastikan pelaksanaan satu-satu dasar dapat direalisasikan secara optimum. Dalam konteks artikel ini, wacana dianalisis sebagai platform yang mengetengahkan takrifan autoriti sebagai realiti sosial dalam bulan penghayatan kebangsaan.

\section{Takrifan Autoriti sebagai Realiti Sosial (Authority-defined as Social Reality)}

Profesor Ulung Shamsul Amri Baharuddin (2007) yang juga merupakan seorang ahli antropologi sosial terkenal telah mengkonseptualkan makna hubungan 'pemerintah-masyarakat' sebagai hubungan yang dibina dan dibentuk oleh 'realiti sosial takrifan autoriti' (authority-defined social reality) dan 'realiti sosial takrifan harian' (everyday-defined social reality) dalam kehidupan masyarakat dan pemerintah di Malaysia. Umumnya di seluruh dunia, himpunan wacana, tulisan dan analisis mengenai budaya terkelompok kepada dua, iaitu yang bersifat 'takrifan autoriti' (authority-defined) dan yang berbentuk 'takrifan harian' (everyday-defined). Konsep takrifan autoriti dan takrifan harian dapat membantu penyelidik yang mengkaji mengenai pembinaan identiti, hubungan antara yang memerintah dan diperintah dan pola perilaku dalam ruang politik (Shamsul Amri, 2011). Hal ini merujuk kepada kuasa untuk mempengaruhi atau memerintah pemikiran, pendapat atau tingkah laku seseorang atau komuniti. Sebuah realiti sosial takrifan autoriti merupakan pandangan realiti yang ditakrifkan oleh pihak berkuasa (seorang sarjana, pegawai kerajaan dan lain-lain) dan digambarkan dalam media.

Shamsul Amri secara kritis menjelaskan bahawa, realiti sosial yang bersifat takrifan autoriti menganjurkan pandangan atau mengemukakan reaksi kepada idea, takrif dan perbincangan mengenai budaya yang diketengahkan oleh pihak yang berkuasa seperti kerajaan, pertubuhan formal, pemimpin yang berwibawa dan penerbitan yang dihasilkan untuk tatapan umum. Sebagai contoh, apabila mantan Perdana Menteri Najib Razak mencetuskan idea mengenai gagasan 1Malaysia, maka kerajaan diarahkan untuk menggunapakai konsep 1Malaysia dalam pentadbiran negara di mana kerajaan akan menganjurkan pelbagai kempen mengenai 1Malaysia melalui media cetak dan media elektronik. Manakala, para menteri pula akan menyentuh mengenai 1Malaysia dalam setiap ucapan dan ceramah masing-masing. Kakitangan kerajaan juga sentiasa diingatkan dengan slogan 1Malaysia. Tidak ketinggalan juga, pihak media massa akan menyiarkan sokongan, komentar dan kritikan daripada semua pihak mengenai gagasan 1Malaysia yang diilhamkan oleh mantan Perdana Menteri itu. Segala perbincangan, tulisan, analisis, bangkangan, kritikan dan juga sokongan terhadap gagasan tersebut terangkum dalam kategori perbincangan mengenai budaya yang bersifat takrifan autoriti. Dengan kata lain, perbincangan itu bergerak dalam satu ruang yang telah ditentukan takrif dan kerangkanya oleh pihak yang berwibawa iaitu kerajaan. Perbincangan itu bersifat terbuka kerana sesiapa sahaja boleh membincangkan mengenainya dan menyuarakan pendapat masing-masing. Namun begitu, dasar kerajaan telah menetapkan sempadan yang perlu dipatuhi. Secara dasarnya, ia merupakan realiti sosial yang ditentukan oleh pemerintah iaitu golongan yang berkuasa.

\section{Takrifan Harian sebagai Realiti Sosial (Everyday-defined as Social Reality)}

Takrifan harian (everyday-defined) ialah realiti sosial yang dialami oleh setiap orang dalam perjalanan kehidupan seharian. Dalam erti kata lain, realiti sosial adalah sesuatu yang dilakukan dan difahami oleh seseorang dalam apa jua perkara yang menunjukkan bagaimana individu menyelami dan 
mempraktikkan budaya mereka. Pengalaman ini dapat dikesan melalui lagu, puisi, blog dan video. Perbincangan mengenai realiti sosial yang bersifat everyday-defined menganjurkan pandangan tentang pelbagai aspek pengalaman budaya, sama ada oleh seseorang individu atau secara berkelompok. Lazimnya, tidak ada kaitan langsung dengan dasar kerajaan mengenai budaya (Shamsul Amri, 2007). Ia pada kebiasaannya bersifat individu atau pengalaman peribadi seseorang serta melibatkan kegiatan atau aktiviti rutin yang sering dilakukan oleh seseorang dalam kehidupan harian yang tiada kaitan dengan dasar kerajaan atau timbul daripada pengaruh globalisasi. Misalnya, budaya popular adalah budaya yang umumnya bersifat everyday-defined yang merakamkan pelbagai pengalaman serta citarasa pelbagai pihak yang tidak semestinya berkongsi pandangan yang sama atau dari satu golongan kelas sosial atau kategori umur. Menurut Shamsul Amri (2011), rakyat Malaysia tanpa segan silu menyuarakan perasaan tidak puas hati mereka terhadap apa saja yang mereka tidak suka. Proses penyuaraan ini lebih memudahkan dengan adanya platform media sosial. Kata kunci yang mendukung pemahaman mengenai budaya bersifat everyday-defined ini adalah 'pengalaman'; sama ada pengalaman seseorang individu atau sesuatu kelompok (Shamsul Amri, 2007). Kepelbagaian pengalaman manusia yang diransang oleh pancaindera untuk memenuhi pelbagai citarasa setiap individu atau kelompok manusia telah mencipta budaya yang bersifat everyday-defined yang cukup kaya lagi rencam (Shamsul Amri, 2007).

Masyarakat dan pemerintah merupakan satu kesatuan yang saling berhubung; di mana masyarakat memerlukan pemerintah kerana ia menyediakan kerangka yang sah bagi perkembangan sesebuah negara. Ini secara langsung meningkatkan kesedaran nasionalisme yang lebih menyeluruh di kalangan masyarakat Malaysia yang pelbagai kaum berhubung persoalan yang lebih bersifat sejagat dan universal. Menerusi kajian ini ditemukan bahawa terdapat penyertaan masyarakat dalam proses membentuk semangat patriotisme terhadap penganjuran kempen bulan Kebangsaan yang berkepentingan nasional dalam negara yang majmuk. Penganjuran MERDEKA@KOMUNITI telah mendapat respon dan sambutan baik dari masyarakat.

\section{Metod Kajian}

Perbincangan kumpulan fokus telah dijalankan untuk melihat pandangan dan persepsi khalayak mengenai fungsi dan kepentingan kempen dalam sambutan Hari Kebangsaan. Temu bual mendalam telah dijalankan selepas perbincangan kumpulan fokus berlansung. Ini bagi mendapatkan maklumat yang lebih lanjut serta mendalam tentang kempen Hari Kebangsaan Malaysia dari golongan profesional. Dapatan yang digarap daripada perbincangan kumpulan fokus dan temu bual mendalam dikaitkan dengan konsep realiti sosial takrifan autoriti sebagai pemangkin kepada pembentukan terhadap penguasaan dalam kalangan rakyat negara ini.

\section{Dapatan Kajian}

\section{Kempen Penghayatan Bulan Kebangsaan}

Setiap tahun perayaan sempena Hari Kebangsaan disambut meriah. Pelbagai kempen dan aktiviti anjuran kerajaan diadakan untuk menyokong bulan Kebangsaan supaya Hari Kebangsaan lebih dihargai oleh semua masyarakat Malaysia khususnya di kalangan remaja dan belia. Apabila responden ditanya mengenai tahap kesedaran mereka tentang kewujudan kempen penghayatan bulan Kebangsaan, mereka memberikan persepsi yang hampir sama. Majoriti responden sedar tentang kempen Hari Kebangsaan anjuran kerajaan sempena sambutan bulan Kebangsaan. Informan yang bertugas sebagai penjawat awam memberitahu bahawa beliau sedar tentang kempen penghayatan bulan Kebangsaan menerusi arahan yang diterima dari pihak majikannya. Menurut beliau, sambut Hari Kebangsaan di sektor kerajaan adalah meriah kerana saban tahun agensi tempat mereka bertugas mewajibkan aktiviti mengebarkan Jalur Gemilang di setiap unit.

Responden 4: Penghayatan Kemerdekaan ni... kalau macam saya seorang tentera ni... dia macam meriahlah sebab tiap-tiap tahun kami macam ... kalau contoh... nak menjelang 31 Ogos tu.... dia ada... seminggu sebelum... diwajibkan kibar 
jalur gemilang... maknanya kami akan agihkan jalur gemilang letak disetiap unitunit... mesti kibarkan... mesti letakkan...

Ada informan yang menyatakan bahawa kesedaran terhadap kewujudan kempen penghayatan bulan Kebangsaan itu tercetus melalui kempen yang dianjurkan kerajaan menerusi media sosial. Hasrat kerajaan untuk menarik minat dan perhatian masyarakat terhadap kempen Hari Kebangsaan menerusi media sosial juga dikatakan berjaya.

Responden 2: Bagi pendapat saya lain... macam bagi pendapat saya orang biasa la ... mcm sebelum ni saya lebih kepada kerja di luar... dulu masa di sekolah cikgu akan mengingatkan tentang Kemerdekaan... tapi sekarang saya macam orang biasa bergantung kepada TV dan sosial media ... itupun masuk bulan Ogos baru la ada... bila masuk pasaraya la... time-time nilah dia ada... hari... promosi Kemerdekaan la apa semua... bila kempen contohnya kita tak tau cuma tema Hari Kemerdekaan tu bila di highlight dalam di TV... mungkin dlm tempoh masuk bulan 8 barulah kita... oooo ok... temanya macam ni-macam ni...

Namun begitu, terdapat informan yang merasakan bahawa kempen Hari Kebangsaan yang wujud sekarang ini adalah lebih bersifat keseronokan berbanding dengan penghayatan erti sebenar Kemerdekaan itu sendiri.

Responden 3: Perarakan Merdeka di dataran ... Kita boleh tengok sekarang mana ada kereta yang ada bendera sangat... (kempen) dia lebih kepada keseronokan... sambutan ... apa yang saya nampak... la ...

\section{Pengaruh 'Takrifan Autoriti' dalam Kempen}

Majoriti informan sedar bahawa terdapatnya unsur "authority-defined" dalam penghasilan kempen Hari Kebangsaan. Seorang sahaja informan yang tidak bersetuju dengan konsep "authority-defined" ini kerana beliau berpandangan bahawa ini merupakan satu perkembangan yang tidak sihat kerana telah mengabaikan nilai-nilai sejarah negara dan lebih memberi fokus terhadap agenda politik semata.

Informan A: ...rasanya ... ini satu perkembangan yang kurang baik kerana ini dah lama-lama tu orang dah tengok tu parti pemerintah... (Semangat) Partiotik tu dah tidak ada... Orang pun dah tidak ada hargai Kemerdekaan... Tidak hargai pemimpin-pemimpin dulu... Sejarah... Sebab tu sekarang orang dah tak kisah lagi sejarah... Satu perkembangan yang tidak sihat...

Informan-informan yang lain pula bersetuju dengan tindakan "authority-defined" yang diamalkan oleh pemerintah kerana mereka berpendapat bahawa dalam mentadbir sesebuah negara, pemerintah tidak boleh meletakkan kuasa pemerintahan kepada rakyat sepenuhnya. Rakyat boleh menyuarakan pendapat mereka, namun pemerintah berhak mempertimbangkannya demi kepentingan negara. Kuasa pemerintahan masih terletak di tangan pemerintah. Oleh yang sedemikian, mereka berpendapat bahawa pemerintah harus bijak menangani setiap isu yang dibangkitkan oleh rakyat serta bijak dalam merencana dan menguruskan pentadbiran negara.

Informan C: ... dia dari segi sebenarnya la ... kerajaan... Pendapat saya la sebenarnya... kalau ikutkan pemerintahan sebenarnya... lagi mudah kalau kerajaan defined. Bila rakyat defined huru hara... Sebenarnya sekarang kalau dekat Malaysia, kerajaan masih lagi lepas 50-50... Rakyat boleh laungkan apa dia nak... Kerajaan masih timbang... Siapa yang pening? Kerajaan yang pening... Yang duduk dalam kerajaan kena sangat bijak... Jadi, bila dia defined tu satu definasi sangat bagus...Dia fikir habis... Dia kena ada satu group pemikir yang sangat bagus... Bukannya old fashion yang tidak boleh follow orang... 
Informan D: ...ooo itu memang betul la ... Kalau dalam politik...Pasal tu kita tidak boleh campur design dengan politik... aaa... Kalau kita cakap secara general... Kalau kita cakap pasal design... Design sahaja... Kalau kita cakap pasal politik... Pasal politik sahaja... Memang ada agenda dan strategi mereka... Jadi, itu tidak boleh salahkan sesiapa... Kalau saya pun sendiri, kalau saya ada agenda... Saya akan masukkan apa yang kepentingan saya la...

\section{Perbincangan}

Kajian 'Takrifan Autoriti sebagai Wacana Realiti Sosial dalam Kempen Penghayatan Bulan Kebangsaan' ini berjaya merumuskan bahawa kempen penghayatan bulan Kebangsaan yang dijalankan dari 2016 hingga 2018 telah memperlihatkan wujudnya satu realiti sosial yang dinamakan 'authoritydefined' yang diwacanakan dengan kemas tetapi padat dengan mesej berkaitan dengan imej dan reputasi serta kemahuan kerajaan untuk dilihat sebagai pihak yang mempunyai autoriti sebagai pemerintah yang berwibawa. Terma takrifan autoriti ini sudah biasa diperkatakan apabila para sarjana membincangkan tentang isu politik dan masyarakat sosial. Namun menerusi kajian ini, dapat mengukuhkan lagi kebenaran yang diperkatakan itu kerana sememangnya telah wujud 'authority-defined' dalam isu yang dikaji. Pemerintah dari awal lagi telah menentukan realiti sosial yang perlu diikuti oleh setiap rakyat dan secara formal ia dijadikan sebagai dasar kerajaan yang menetapkan garispanduan yang bersifat birokratik yang perlu dipatuhi oleh semua pihak. Ini yang berlaku terhadap kempen penghayatan bulan Kebangsaan 2016-2018. Penghasilan kempen MERDEKA@KOMUNITI tersebut telah mendapat sambutan hebat dari masyarakat seluruh negara dan dalam masa yang sama pemerintah masih percaya bahawa menerusi kempen seperti ini, mesej 'authority-defined' berupaya menonjolkan kuasa mereka sebagai kerajaan yang memerintah negara ini. Pemerintah berkuasa menentukan pengisian dalam setiap kempen yang diatur namun dalam masa yang sama masih berteraskan kepada kehendak rakyat asalkan tidak menggugat kredibiliti mereka. Menerusi kajian ini, didapati bahawa authority-defined lebih dominan. Maka, pihak yang dominan mengekalkan sesuatu penguasaan yang telah diperolehi tanpa digugat oleh pihak yang minoriti.

Wacana takrifan autoriti menerusi mesej rasmi kerajaan sebagai penggubal dasar yang ingin disampaikan kepada rakyat menerusi acara-acara serta media dalam kempen Hari Kebangsaan haruslah mempunyai tujuan, matlamat, konteks dan sosial. Berdasarkan prinsip 'authority-defined', kempen bulan Kebangsaan pada tahun 2016 hingga 2018 adalah dikawal oleh pemerintah. Pemerintah telah merencana dan merancang segala aktiviti kempen menerusi program MERDEKA@KOMUNITI. Segala aktiviti dan program yang berlansung sepanjang bulan Kebangsaan tersebut adalah di bawah arahan dan tanggungjawab pemerintah. Di sini, didapati bahawa kuasa pemerintah yang dominan, berkuasa menentukan bentuk program dan aktiviti kempen yang harus dilaksanakan untuk sambutan Hari Kebangsaan tahun 2016 hingga 2018.

Penganjuran MERDEKA@KOMUNITI telah mencetuskan satu fenomena baharu. Sebelum ini, kempen bulan Kebangsaan hanya berdiri atas satu matlamat khusus yang berpaksikan kepada sejarah perjuangan Kemerdekaan dan pembentukan negara dan masyarakat yang membangun serta berdaya saing. Namun, penganjuran MERDEKA@KOMUNITI pada tahun 2016-2018 didapati mempunyai sebab dan alasan yang tersendiri oleh kerajaan demi memastikan misi dan matlamat kerajaan untuk mengeratkan silaturrahim di kalangan segenap lapisan masyarakat seluruh Malaysia tercapai.

\section{Kesimpulan}

Kajian ini adalah mengenai kempen penghayatan bulan Kebangsaan dan takrifan autoriti sebagai realiti sosial dari pemerintah kepada rakyat dan sejauh mana takrifan autoriti berpengaruh dalam membangkitkan semangat patriotisme menerusi kempen penghayatan bulan Kebangsaan. Bagi sesebuah negara yang sedang membangun, peranan pemerintah dalam memanipulasi sesuatu perkara adalah sangat penting demi mengawal sesuatu penguasaan yang telah diperolehi. Ini penting untuk membentuk 
masyarakat negara bangsa yang bersatu dengan pemerintah dalam membangunkan negara ke tahap pencapaian yang terulung di mata dunia. Jatuh bangunnya negara kita dan hidup matinya bangsa kita adalah tanggungjawab kita semua untuk menentukannya (Ruhanie, 2005). Kajian ini secara intelektualnya telah berusaha untuk mengupas dan memahami strategi pemerintah yang cuba disalurkan menerusi kempen penghayatan bulan Kebangsaan yang pada dasarnya kurang mendapat perhatian daripada masyarakat sehinggalah wujudnya penganjuran program MERDEKA@KOMUNITI pada tahun 2016-2018.

Menerusi kajian yang lepas, didapati bahawa generasi baharu tidak peka dan akur kepada wacana semangat kebangsaan melalui seruan untuk mengibarkan Jalur Gemilang dan sebagainya. Hal ini menimbulkan keresahan dalam diri pengkaji kerana semangat patriotisme dalam diri generasi baharu semakin hilang sedikit demi sedikit dan jika masalah ini tidak dibendung dari sekarang, dikhuatiri ianya akan lenyap sama sekali. Kekuatan masyarakat Malaysia bergantung kepada perpaduan dan komitmen pelbagai kaum untuk bangun, berjuang dan membuat perubahan.

Untuk merealisasikan impian dan wawasan membentuk sebuah negara yang maju dan berdaulat, generasi muda pada hari ini perlu mempunyai kesedaran dan keberanian mengambil tanggungjawab mempertahankan negara dari segala bentuk ancaman. Ini hanya berlaku sekiranya dalam diri setiap anak muda masyarakat Malaysia ada tersemat semangat nasionalisme dan patriotisme yang menjadi kunci kekuatan semangat dalam sanubari masyarakat Malaysia.

Jawapan informan amat membantu penyelidik untuk memahami bahawa kempen penghayatan bulan Kebangsaan anjuran kerajaan itu berjaya menerapkan kesedaran terhadap semangat patriotisme dalam kalangan belia. Menerusi kempen yang dianjurkan, masyarakat memahami mesej yang disampaikan oleh kerajaan dan menyokong penuh usaha yang dilakukan untuk memupuk semangat patriotisme. Melalui perbincangan kumpulan fokus dan temu bual mendalam yang dijalankan, didapati masyarakat mengakui kepentingan kempen penghayatan Hari Kebangsaan yang dianjurkan oleh kerajaan dalam membentuk semangat patriotisme dalam diri. Penghasilan kempen yang betul, mampu membangkitkan semangat patriotisme dalam diri masyarakat terhadap negara. Menerusi kempen yang dianjurkan, ia secara tidak lansung telah berjaya menyedarkan masyarakat tentang kepentingan penyatuan masyarakat pelbagai kaum di Malaysia.

Aktiviti-aktiviti yang dilakukan menerusi kempen penghayatan Hari Kebangsaan telah menyerlahkan keperibadian masyarakat Malaysia. Masyarakat menyambut baik kempen yang dianjurkan oleh kerajaan dengan mengambil bahagian dalam kempen-kempen tersebut. Partisipasi dari masyarakat ini merupakan ciri-ciri penting ke arah pembentukan semangat patriotisme dalam kalangan masyarakat sivil yang efektif. Apabila masyarakat mula memberi respon, ini bermakna mereka peka (alert) dan mereka mengambil berat tentang sesuatu kempen. Sekiranya tiada langsung tindak balas atau respon yang dilakukan bermakna usaha kerajaan mengadakan kempen-kempen penghayatan Hari Kebangsaan adalah sia-sia dan tidak ada fungsinya serta tidak memberikan apa-apa makna. Masyarakat akan menolak (ignore) dan cenderung menunjukkan sikap tidak mengambil tahu serta tidak mahu mengambil bahagian dalam apa-apa kempen yang dianjurkan.

Kempen penghayatan Hari Kebangsaan sememangnya penting dalam membentuk semangat patriotisme dalam kalangan masyarakat. Sungguhpun begitu, usaha menanam dan mencorakkan semangat patriotisme ini hanya dapat dijayakan sekiranya kempen dirancang dan dilaksanakan dengan betul, ia mampu membangkitkan semangat patriotisme dalam diri masyarakat terhadap negara.

Di samping itu, agensi-agensi kerajaan di bawah Kementerian Komunikasi dan Multimedia Malaysia seperti Jabatan Penerangan Malaysia dan Jabatan Penyiaran Malaysia perlu seiring dari segi kemahuan audien yakni rakyat masakini. Penggunaan media sosial dan penghasilan kandungan wacana yang kreatif seharusnya dapat menjentik hati dan mendorong timbulnya set pemikiran yang jelas terhadap semangat patriotisme dalam kalangan rakyat khususnya generasi baru. 
Malaysian Journal of Social Sciences and Humanities (MJSSH), Volume 5, Issue 8, (page 1 - 12), 2020

DOI: https://doi.org/10.47405/mjssh.v5i8.455

\section{Rujukan}

Abd Rahim Abd Rashid (2004). Patriotisme: Agenda Pembinaan Bangsa. Kuala Lumpur. Utusan Publications \& Distributors Sdn Bhd.

Ashiqin Rosselly (15 Ogos 2018) Siapa Tak Kenal Tan Hong Ming? 15 Iklan Merdeka Yang Mampu Pupuk Semangat Cintakan Negara Dipetik daripada: https://says.com/my/seismik/iklan-merdekalama diakses pada 25 April 2019

Asmah Omar. 1986. Bahasa dan Alam Pemikiran Melayu. Kuala Lumpur. Dewan Bahasa dan Pustaka.

Billig, M. (1993). Studying Nationalism as an Everyday Ideology. Papers on Social Representation, 2(1), 40-43.

Billig, M. (1995). Banal Nationalism. London: SAGE Publications Ltd.

Baldi,P \& Hasebrink, U. (2007). Broadcasters and Citizens in Europe: Trends in Media Accountability and Viewer Participation.UK: Intellect Books

Christopher McMahon. (1994). Authority and Democracy. A General Theory of Goverment and Management. New Jersey: Princeton University Press.

Djajasudarma, F. (2012). Wacana dan Pragmatik. Bandung: PT. Refika Aditama.

Eko Prayitno Joko, Zaini Othman \& Saat Awg. Damit. (2016). Belia dan Kelansungan Hegemoni Barisan Nasional: Kajian Kes Pilihan Raya Umum 13 di Sabah. Jurnal Komunikasi Borneo (Edisi Khas Konvekesyen ke-18 UMS)

Fairclough, N. (1995). Critical Discourse Analysis: The Critical Study of Language. Harlow: Longman.

Faridah Ibrahim, Badrul Redzuan (2012). Membangun "Sinema Sikap": Memproblematik Hubungan Kekuasaan Melayu-Tionghua dalam Mukhsin. Jurnal Komunikasi Jilid 27(2), 137-160.

Hobsbawm, E \& Ranger, T. (1983). The Invention of Tradition. Cambridge: Past and Present Publications

Hodge, R. \& G. Kress. (1988). Social Semiotics. Cambridge: Polity

Hodge, R. (1990) Literature as Discourse: Textual Strategies in English and History. Polity Press.

Idris Aman. (2000). Bahasa, Kuasa, dan Ideologi: Analisis Wacana Kritis Sebutan Baku Bahasa Melayu. AKADEMIKA, 56, 121-133.

Jewitt, C \& Oyama, R. 2001. Visual Meaning: A Social Semiotic Approach. London. SAGE Publications.

Kress, G. (2009) Critical Discourse Analysis dlm. Robert Kaplan, ed., Annual Review of Applied Linguistics, Vol. II.

Kress, G. (2010) Multimodality: A Social Semiotic Approach to Contemporary Communication. New York. Routledge.

Kress, G. (2012) Multimodal: Discourse Analysis. New York. Routledge.

Mohd. Foad Sakdan. (1997). Pengetahuan Asas Politik Malaysia. Kuala Lumpur. Dewan Bahasa dan Pustaka.

Moriarty, S. and Duncan, T. (1990). How to Create and Deliver Winning Advertising Presentations. United States of America. NTC Business Books.

Nayan Ahmad. (1984). Komunikasi Visual Kewartawanan Foto. Kuala Lumpur. Dewan Bahasa dan Pustaka.

Potter, J \& Wetherell, M. (1992). Re-representing representations: discussion of Raty and Snellman. On-going production on Social Representations, 1, 15-20.

Ricoeur, P. (1986). Lectures on Ideology and Utopia. New York: Columbia University Press.

Shirato, T., Yell, Susan. (2000) Communication and Culture: An Introduction. Australia: Allen \& Unwin.

Sitinurbayu \& Badrul Redzuan. (2014). Implikasi Komunikatif Logo Hari Kemerdekaan: Sebuah Nota Penyelidikan. Jurnal Komunikasi, 30(1), 199-219

Syahruddin Hj. Awg. Ahmad. (2015). Aplikasi Model Analisis Proposisi Bingkai DPM dan Justifikasi Pendapat dalam Wacana di Laman Sosial dan Portal Berita. Jurnal Komunikasi Borneo, 2.

Tarigan, Henry Guntur. 2009. Pengajaran Wacana. Bandung. Penerbit ANGKASA.

Van Leeuwen, T. (2005) Introducing Social Semiotics. London. Routledge.

Wan Mohd Nor Wan Daud. (2015). Patriotisme dan Ketatanegaraan. Kuala Lumpur: Arial Communications Sdn Bhd 
Malaysian Journal of Social Sciences and Humanities (MJSSH), Volume 5, Issue 8, (page 1 - 12), 2020

DOI: https://doi.org/10.47405/mjssh.v5i8.455

Yang Yang. (2016). A Social Semiotic Approach to Multimodal Discourse of the Badge of Xi'an Jiaotong University. Theory and Practice in Language Studies, 6(8), 1596-1601.

Zainal Abidin Abdul Wahid et al. (1996). Malaysia: Warisan dan Perkembangan. Kuala Lumpur. Dewan Bahasa dan Pustaka.

Zarina Othman, et al. (2016). Memelihara keselamatan Negara Malaysia: Peristiwa Lahad Datu, Sabah. GEOGRAFIA Online ${ }^{\mathrm{TM}}$ Malaysian Journal of Society and Space 12(7), 147-159. 